Article

\title{
Physicochemical Analysis and Essential Oils Extraction of the Gorse (Ulex europaeus) and French Broom (Genista monspessulana), Two Highly Invasive Species in the Colombian Andes
}

\author{
Diego F. Osorio-Castiblanco, Gwendolyn Peyre and Juan F. Saldarriaga *(D) \\ Department of Civil and Environmental Engineering, Universidad de los Andes, Cra 1E \# 19A-40, \\ Bogotá 111711, Colombia; df.osorio12@uniandes.edu.co (D.F.O.-C.); gf.peyre@uniandes.edu.co (G.P.) \\ * Correspondence: jf.saldarriaga@uniandes.edu.co or juanfelorza@gmail.com
}

Received: 16 October 2019; Accepted: 28 November 2019; Published: 19 December 2019

\begin{abstract}
Gorse (Ulex europaeus) and French broom (Genista monspessulana) are two highly invasive species that have become a threat to tropical countries, especially in Andean ecosystems. This research focused on providing a physicochemical characterization and essential oils extraction of both species to better understand their potential valorization and guide further environmental management efforts. For this purpose, the following analyses were conducted for both species: higher heat value (HHV), elemental analysis, proximate analysis, thermogravimetric analysis to obtain constituent natural polymers (hemicellulose, cellulose, and lignin), and extraction of essential oils and other interest chemical compounds through supercritical fluids. Ecological closeness was found between the two species mostly regarding HHV, fixed carbon, and volatile matter, which calls for similar potential uses. Both species were also found to be suitable for combustion processes, gasification, extraction of chemical compounds, and use of lignocellulosic content; however, only U. europaeus appeared suitable for activated carbon obtention. Therefore, this work provided relevant data that can be used as preliminary basis to establish strong scientifically-based management and control strategies for these two invasive species. We recommend focusing primarily on thermal processes such as pyrolysis, gasification, or combustion, and also essential oils extractions of acetic acid, dodecanoic acid, anagyrine, amylene hydrate, caulophylline, and maltol in the future.
\end{abstract}

Keywords: Andes; Genista monspessulana; invasion; physicochemical characterization; Ulex europaeus; valorization

\section{Introduction}

The critical damage caused by invasive species has made this threat the second cause of biodiversity loss worldwide. This is often due to increased competition, depredation, or transmission of diseases that directly affect native species, their interactions, and the ecosystem services they provide [1]. In Colombia, the threats posed by invasive species to natural megadiverse and fragile ecosystems are substantial; however, the Colombian government only recognizes 22 invasive species at the national scale, including nine invertebrate, eight fish, and five plant species to date [2,3], and there is no comprehensive assessment of the causes and impacts of the subsequent invasions [4]. Due to the magnitude of the threat paired with other environmental problematics such as uncontrolled deforestation, important pollution, and climate change, there is an urgent need to offer a more complete overview of the species present in the country, their distribution, adaptations, and consequences for natural ecosystems and human wellbeing. Furthermore, it is a priority to propose management 
strategies for such species, understanding how their removal and/or use can be carried out with minimum environmental impact and hopefully human benefits [5,6].

Ulex europaeus L. and Genista monspessulana (L.) L.A.S. Johnson are Fabaceae shrubs with similar origin, the former coming principally from the humid and semi-humid lowlands and montane areas of Western Europe, while the latter is most common in Mediterranean and sub-Mediterranean regions. They are both ranked as very aggressive invasive species, especially in tropical highlands and the subtropics, U. europaeus being in the top 100 of the World's Worst Invasive Alien Species list provided by the Global Invasive Species Database [7], and the top 10 for Colombia [8]. Their invasive success is due to several shared factors. First, their growth rates are important; for example U. europaeus can grow up to $500 \mathrm{~mm} /$ year as a young individual and $100-200 \mathrm{~mm} /$ year as a mature one [9]. Second, they invest in important seed production, up to 9000 seeds $/ \mathrm{m}^{2}$ for G. monspessulana and between $500-20742 \mathrm{seeds} / \mathrm{m}^{2}$ for U. europaeus [10-12]. Third, they reach maturity very early, e.g., at two years for G. monspessulana, and flower almost all year along in tropical countries due to the absence of strong seasonal effects $[2,13]$. Fourth, they are highly resilient to disturbances, cuts, and fire events by the means of a persistent strong soil seed bank and easy resprouting [14-16]. Fifth, they often form dense, compact, and homogeneous colonies, and present high spines density in the case of $U$. europaeus, which often exclude neighboring species due principally to their structure, shading, and rainwater interception [5,13]. Finally, they are adaptable to a wide range of climatic conditions and are also able to form mycorrhizal interactions with Bradyrhizobium and Rhizobium among others, which facilitates establishment and persistence on poor soils [17].

The earliest known introduction of U. europaeus to Colombia goes back to the 1950s, when the Aqueduct of Bogota company massively imported the species to build natural living green fences around the Regadera and Chisaca reservoirs (Lat. 4.40, Long. 74.14 [18]). Similarly, there are some reports of plantations of G. monspessulana by the Autonomous Regional Corporation of Cundinamarca around 1997 in the Tominé Reservoir, Simijaca, Zipaquirá, and Madrid (Lat. 4.96, Long. 73.83 [19]). Today, U. europaeus and G. monspessulana are mostly found in Andean montane environments, which in the tropics often mimic temperate regions regarding temperature and precipitation. These species are usually growing in colonies, which can reach great extension and abundance of more than 100 individuals, and are often located near disturbed areas for grazing, roads and trails, and agriculture [2,14]. U. europaeus and G. monspessulana are respectively classified with a 7.39 and 6.56 out of 10 in the Risk Analysis of Introduced Plant Species for Colombia [5]. Both species are known to greatly impact the ecosystems they invade, for example, by altering the natural nitrogen cycle due to their important nitrogen intake, resulting in soil rapid impoverishment and affectation in the survival, germination, and growth of other plant species [20,21]. In addition, these species often change the hydrological balance of the invaded ecosystems by quickly removing water from the immediate habitat that often leads to water stress and delays ecological cycles, including ecological successions $[5,22]$. They have also been associated with increased fire risks, mostly because of their permanent necromass that acts as fuel during dry seasons $[15,16]$. Since they are both adapted to high levels of environmental disturbance and stress, it is common to find the plants at ecotones with ecosystems of high ecological or conservation value, such as Andean forests, putting at risk the structural and functional equilibrium of said ecosystems. To date, observed changes in invaded tropical Andean ecosystems by these species include dominance of colonies, deterioration of ecosystem services, especially regulating and supporting ones, changes in ecological succession patterns, as well as loss of native biodiversity $[2,23]$.

Worldwide, management strategies have been proposed to control, reduce, or remove these species with different success rates highly dependent on the local environmental, population and cultural conditions. For example, U. europaeus has been treated with shade by planting high trees around, fire to reduce seed population, herbicides, mechanical control, and biological control with weevil and spider mite species [23]. Regarding G. monspessulana, different strategies have been applied, including crop control with goats or burnings, mechanical control, herbicides, biological control with 
psyllids, and everyday uses as brooms and in horticulture [2,24]. The environmental management, control, and removal of $U$. europaeus and G. monspessulana are particularly challenging in tropical countries because they remain used in horticulture, especially for edge building, from which they often escape and spread to adjacent ecosystems. In addition, manual removal can lead to management mistakes, including accidental seed dispersal or easy resprouting from partial removal of the aerial biomass $[2,23,24]$. Public knowledge on these species' impacts on ecosystems remains scarce, although environmental education is increasing, which makes their management particularly complicated $[25,26]$. As a result, uniformizing and standardizing procedures are urgently required to develop ex-situ valorization of both species. Towards that goal, it is crucial to provide novel fundamental knowledge on the potential uses of these species based on their physicochemical properties in order to issue better-sustained management proposals, for example through harvest and potential commercialization to boost removal efforts [27].

Of the two species, $U$. europaeus is the most studied in terms of valorization of all its parts. $U$. europaeus has been used for livestock feed and fuel [28], bioherbicide [29], and compost [30]. In addition, components with biomarker [31], antiviral, antibacterial [32], fatty acid [33], and raw material for biopolymers properties have been extracted from the plant's tissues. A recent study also conducted an overall primary analysis of $U$. europaeus by characterizing its elemental, immediate, and lignocellulosic composition seeking a thermochemical valorization of this species [34]. Despite such efforts, further uses and/or valorization could be put forward in order to better exploit the species' components and feed a circular economy. Unlike U. europaeus and although they share evolutionary, anatomic, and ecological similarities, no attempts of physicochemical characterization had been conducted for G. monspessulana to date.

The overarching goal of this study was to analyze and compare the physicochemical characteristics of $U$. europaeus and G. monspessulana to provide bases for exploring new management strategies in the future. Specifically, (i) the hemicellulose, cellulose, and lignin contents were determined, (ii) the kinetic degradation was evaluated through elemental analysis, immediate analysis, heating value, and hemicellulose/cellulose/lignin ratio, and (iii) extractions of super-critical fluids were conducted on different plant vegetative and reproductive parts in order to determine the essential oils contents.

\section{Methods}

\subsection{Data Sampling and Handling Procedure}

According to the bioclimatic range of $U$. europaeus and G. monspessulana species, their potential distribution covers most of the montane belt in the Colombian Andes (Figure 1). Occurrences have been observed mostly in peri-urban areas for G. monspessulana to date, whereas a much wider range has been recorded for $U$. europaeus. In the latter case, such rapid expansion is attributed to long-distance seed dispersal through roads and disturbed areas, e.g., through crops, reaching higher mountain areas similar to temperate regions $[35,36]$.

Plant samples from both species were collected at similar elevations representative of the high Andean belt (2500-3000 m.a.s.l.) near Bogota and in open areas for pastures near transited trails. Due to accessibility and plant availability with important colonies, G. monspessulana was collected at the Santa Fe locality (Lat. 4.60, Long. 74.06), and U. europaeus at the Usme locality next to the Paramo de Sumapaz (Lat. 4.33, Long. 74.20). In both cases, 11 randomly picked mature individuals were sampled, collecting in the mid-section of the plant and under different angles at least three ramets for stems and leaves (ligneous and $>20 \mathrm{~cm}$ ) and three more for flowers and fruits (mixed fructiferous and flowering branches, $>10 \mathrm{~cm}$ ). When collecting, all samples were kept separated between vegetative (stems and leaves) and reproductive (flowers and fruits) ramets and contained in codified Ziploc bags. They were later brought to the Environmental Engineering Research Center laboratory of the University of the Andes where they were stored at $4{ }^{\circ} \mathrm{C}$ for several days. For each individual, samples were then carefully handled to separate leaves, stems, flowers and seeds from fruits using dissection tongs. All samples of 
the same organ, were then merged together by species, dried at $105^{\circ} \mathrm{C}$ for $24 \mathrm{~h}$ and finally triturated for $5 \mathrm{~min}$ in a Retsch shredder to obtain a minimum of $100 \mathrm{~g}$ for triplicate. The samples were then submitted to an analysis of biomass and lignocellulosic characterization, and essential oils extraction.
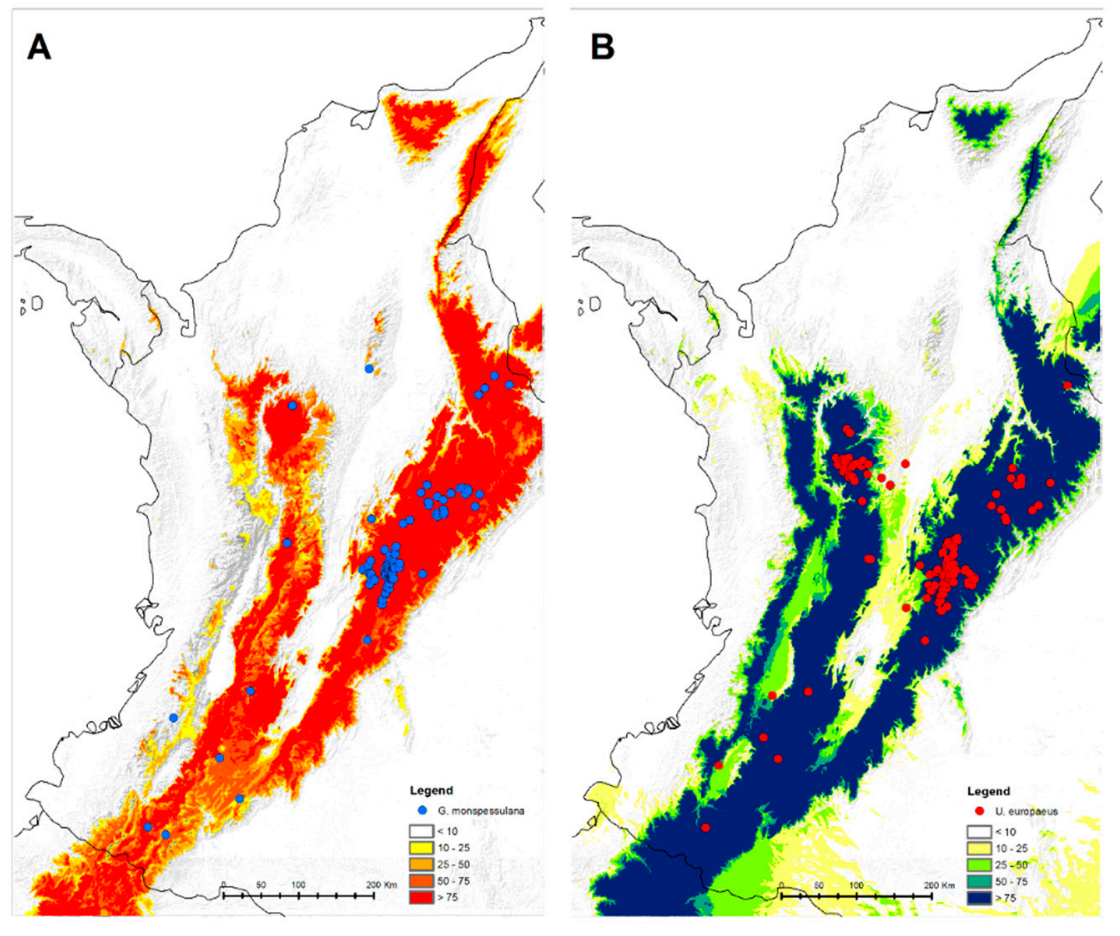

Figure 1. Potential distribution of (A) G. monspessulana and (B) U. europaeus based on environmental species distribution models for Colombia. The models were carried out in R.3.3.1 (package biomod2 [37]).) and predicted the probability of presence of a species (as a percentage) using the Generalized Linear Model and Random Forest algorithms, actual distribution points obtained from national public databases (2015-2019) and four environmental variables selected to either encompass environmental stress or on the contrary promote plant growth from the CHELSA bioclimatic database (www.chelsa-project.org, variables bio11- Mean Temperature of Coldest Quarter, bio12- Annual Precipitation, bio15- Precipitation Seasonality and bio18- Precipitation of Warmest Quarter, [38])).

\subsection{Biomass Characterization}

Four commonly used analyses were conducted to characterize the biomass of the different plant samples, including moisture content, proximate, elemental and higher heat value analyses according to Saldarriaga et al. [39]. To do this, the moisture content was determined according to ISO589 standard, proximate analysis in a TA Instrument TGA 5500 Discovery (New Castle, DE, USA), elemental analysis according to ASTM D5373 and ISO19579 standards in an Elemental Vario Macro model, and higher heating value HHV according to ASTM D5865 standard in a Parr 6200 isoperibolic bomb calorimeter (Moline, IA, USA).

\subsection{Lignocellulosic Characterization}

The methodology developed by Saldarriaga et al. [39] was used to obtain the lignocellulosic characterization of the two species of interest. This methodology is based on the deconvolution of the DTG curve which clearly separates the peaks corresponding to the degradation of the three natural polymers hemicellulose, cellulose, and lignin contained in the biomass. An algorithm was written in Scilab and developed according to Saldarriaga et al. [39], which uses a subroutine based on the Adams method (for non-stiff ODE problems) for an integration of ordinary differential equations that describe the weight loss associated with the degradation of the three components. It also uses a Fminsearch subroutine (based on the Nelder and Mead algorithm) for the optimization of parameters 
for better adjustment of results. The equipment used for this procedure was the TGA Discovery 5500, TA Instruments.

\subsection{Extraction of Essential Oils and Other Chemical Compounds of Interest}

The methodology used to conduct the supercritical fluid extraction process followed the protocol established by Gaspar et al. [40]. The high pressure Soxhlet Extractor brand JW Scientific model 10232-F was used. For the process, the solvents dichloromethane and methanol were used in a 1:1 ratio. It was placed in a water bath between 45 to $50^{\circ} \mathrm{C}$ in a water leaf over $6 \mathrm{~cm}$ for $1.5 \mathrm{~h}$.

The extracts were put into flasks in a water-bath over $60^{\circ} \mathrm{C}$ to remove the solvents. The concentrated extracts were then run by the presence-absence method of volatile organic compounds (VOC) by gas chromatography coupled to mass spectrometry. A $6890 \mathrm{~N}$ gas chromatograph coupled to a selective mass detector 5975B (electronic impact) of Agilent Technologies (Santa Clara, CA, USA) was used. A volume of $1 \mu \mathrm{L}$ of extract was injected. The initial temperature of the column was $40^{\circ} \mathrm{C}$ and was brought to $200^{\circ} \mathrm{C}$ at a heating rate of $3{ }^{\circ} \mathrm{C} / \mathrm{min}$. Then, a heating rate of $10^{\circ} \mathrm{C} / \mathrm{min}$ was applied up to $250^{\circ} \mathrm{C}$ and it was left isothermal for $5 \mathrm{~min}$. Splitless mode was used at an initial temperature of $250^{\circ} \mathrm{C}$ and pressure of $7.15 \mathrm{psi}(49.3 \mathrm{kPa})$. The carrier gas was helium at a flow rate of $1.0 \mathrm{~mL} / \mathrm{min}$. An Agilent 19091S-133 HP-5MS column was used (30 $\mathrm{m} \times 0.250 \mathrm{~mm} \times 0.50 \mu \mathrm{m})$. The data acquisition mode was Scan in a mass range of 40 to 550 uam (units of atomic mass). The temperature of the ion source was $230^{\circ} \mathrm{C}$ and of the quadrupole $150{ }^{\circ} \mathrm{C}$.

The chemical compounds detected by the chromatograph were reported for the eight samples with a certainty percentage higher than $70 \%$ regarding the software library of the selective mass detector. The units reported correspond to the relative amount and are equivalent to the percentage of the area of each compound with regards to the total area of all the compounds, but it is not equivalent to concentration.

\subsection{Statistic Analysis}

All analyses were performed in triplicate, in order to guarantee the reproducibility of the results. The results of the kinetic parameters were obtained from the models developed by Saldarriaga et al. [34,39], in which a model was developed to obtain the kinetic constant and the activation energy at the reference temperature. This has been done based on an objective function which was defined as the sum of squared differences between the experimental and calculated data [34,39]. The objective function as proposed by Saldarriaga et al. [39] was minimized by an optimization subroutine fminsearch (based on the Nelder-Mead algorithm).

\section{Results}

\subsection{Biomass Characterization}

Table 1 shows the HHV, elemental composition, and moisture, volatile matter, fixed carbon, and ashes values for each functional part of $U$. europaeus and $G$. monspessulana. Both species showed very similar elemental composition overall. Regarding the HHV, stems, flowers, and seeds showed values very close to each other for both species like pine sawdust that presents an $\mathrm{HHV}$ of $18.84 \mathrm{~kJ} \mathrm{~mol}^{-1}$ [39]. For $U$. europaeus, the highest value was in a range between 18.41 and $20.83 \mathrm{MJ} / \mathrm{kg}$ and the highest value was found in seeds, while, for G. monspessulana, it was between 19.33 and $21.61 \mathrm{MJ} / \mathrm{kg}$ and the highest value was found in leaves. A difference was observed for leaves, typically higher in G. monspessulana than U. europaeus.

In general, the moisture content observed was low in all samples; this could probably be due to the pretreatment that the samples underwent upon arrival at the lab. Moreover, all functional parts of $G$. monspessulana showed a very low fixed carbon content, while those of $U$. europaeus had a relatively high content. Finally, U. europaeus showed lower contents of volatile matter and higher ash contents than G. monspessulana. 
Table 1. Proximate and elemental analysis measured for the biomass characterization of different functional parts flower, leaves and stems for U. europaeus (G) and G. monspessulana (FB).

\begin{tabular}{ccccccccc}
\hline \multirow{2}{*}{ Property } & \multicolumn{7}{c}{ Functional Part Analyzed } \\
\cline { 2 - 9 } & G-Flower & FB-Flower & G-Leaf & FB-Leaf & G-Seed & FB-Seed & G-Stem & FB-Stem \\
\hline HHV (MJ/kg) & 18.41 & 19.33 & 19.11 & 21.61 & 20.83 & 20.76 & 19.15 & 19.35 \\
C (wt. \%. d.b.) & 42.10 & 42.50 & 45.70 & 45.90 & 45.80 & 46.50 & 44.50 & 44.40 \\
H (wt. \%. d.b.) & 5.85 & 6.23 & 6.08 & 6.17 & 6.44 & 6.49 & 5.78 & 5.92 \\
N (wt. \%. d.b.) & 2.23 & 2.54 & 2.19 & 3.53 & 5.28 & 4.51 & 1.51 & 1.45 \\
S (wt. \%. d.b.) & 0.46 & 0.60 & 0.49 & 0.66 & 0.47 & 0.50 & 0.51 & 0.34 \\
O (wt. \%. d.b.) & 49.36 & 48.13 & 45.54 & 43.74 & 42.01 & 42.00 & 47.70 & 47.89 \\
Moisture (wt. \%. w.b.) & 0.38 & 0.41 & 0.40 & 0.37 & 0.56 & 0.58 & 0.16 & 0.04 \\
Volatile matter (wt. \%. d.b.) & 85.05 & 96.44 & 81.28 & 93.16 & 88.75 & 96.24 & 82.47 & 97.47 \\
Fixed carbon (wt. \%. d.b.) & 11.12 & 0.21 & 12.30 & 3.84 & 6.76 & 0.003 & 13.05 & 0.54 \\
Ashes (wt. \%. d.b.) & 3.51 & 2.95 & 6.10 & 2.66 & 4.00 & 3.18 & 4.35 & 1.96 \\
\hline
\end{tabular}

\subsection{Thermogravimetric Analysis}

According to the thermogravimetric analyzes of both species, it was possible to determine the amount of hemicellulose, cellulose, and lignin of each of the components evaluated, as well as the activation energy and the kinetic constant of each of them. It was observed that, in all the analyzed samples, cellulose was the component with higher activation energy, while lignin had minor activation energy (Table 2).

Table 2. Pyrolysis kinetic parameters and content of hemicellulose, cellulose, and lignin calculated for the different functional parts flower, leaves and stems of U. europaeus (G) and G. monspessulana (FB).

\begin{tabular}{|c|c|c|c|c|}
\hline Functional Part & Kinetic Parameter & Hemicellulose & Cellulose & Lignin \\
\hline \multirow{3}{*}{ G-flower } & $\operatorname{Ln~k}_{0}\left(\mathrm{~s}^{-1}\right)$ & 5.42 & 13.26 & 1.30 \\
\hline & $\mathrm{E}\left(\mathrm{kJ} \mathrm{mol}^{-1}\right)$ & 50.32 & 93.04 & 41.28 \\
\hline & Content $(\% \mathrm{p} / \mathrm{p})$ & 26.24 & 28.65 & 40.73 \\
\hline \multirow{3}{*}{ FB-flower } & $\operatorname{Ln} \mathrm{k}_{0}\left(\mathrm{~s}^{-1}\right)$ & 2.00 & 4.43 & 1.52 \\
\hline & $\mathrm{E}\left(\mathrm{kJ} \mathrm{mol}^{-1}\right)$ & 35.32 & 50.04 & 51.28 \\
\hline & Content $(\% \mathrm{p} / \mathrm{p})$ & 29.68 & 29.01 & 37.82 \\
\hline \multirow{3}{*}{ G-leaf } & $\operatorname{Ln} k_{0}\left(s^{-1}\right)$ & 9.36 & 6.97 & 13.65 \\
\hline & $\mathrm{E}\left(\mathrm{kJ} \mathrm{mol}{ }^{-1}\right)$ & 70.32 & 64.04 & 111.28 \\
\hline & Content (\% p/p) & 26.99 & 35.50 & 30.86 \\
\hline \multirow{3}{*}{ FB-leaf } & $\operatorname{Ln~}_{0}\left(\mathrm{~s}^{-1}\right)$ & 5.43 & 7.01 & 5.90 \\
\hline & $\mathrm{E}\left(\mathrm{kJ} \mathrm{mol}{ }^{-1}\right)$ & 50.32 & 63.04 & 69.28 \\
\hline & Content (\% p/p) & 26.94 & 33.93 & 35.74 \\
\hline \multirow{3}{*}{ G-seed } & $\operatorname{Ln~}_{0}\left(\mathrm{~s}^{-1}\right)$ & 4.82 & 12.62 & 1.30 \\
\hline & $\mathrm{E}\left(\mathrm{kJ} \mathrm{mol}^{-1}\right)$ & 50.32 & 93.04 & 41.28 \\
\hline & Content (\% p/p) & 27.52 & 30.06 & 37.70 \\
\hline \multirow{3}{*}{ FB-seed } & $\operatorname{Ln} k_{0}\left(s^{-1}\right)$ & 4.94 & 12.09 & -0.13 \\
\hline & $\mathrm{E}\left(\mathrm{kJ} \mathrm{mol}^{-1}\right)$ & 50.32 & 89.04 & 45.28 \\
\hline & Content $(\% \mathrm{p} / \mathrm{p})$ & 34.47 & 33.79 & 27.96 \\
\hline \multirow{3}{*}{ G-stem } & $\operatorname{Ln~}_{0}\left(\mathrm{~s}^{-1}\right)$ & 11.99 & 20.84 & 5.40 \\
\hline & $\mathrm{E}\left(\mathrm{kJ} \mathrm{mol}^{-1}\right)$ & 80.32 & 130.94 & 61.28 \\
\hline & Content $(\% \mathrm{p} / \mathrm{p})$ & 24.95 & 30.50 & 39.78 \\
\hline \multirow{3}{*}{ FB-stem } & $\operatorname{Ln~k}_{0}\left(\mathrm{~s}^{-1}\right)$ & 7.35 & 14.87 & 5.28 \\
\hline & $\mathrm{E}\left(\mathrm{kJ} \mathrm{mol}^{-1}\right)$ & 60.32 & 100.04 & 65.28 \\
\hline & Content $(\% \mathrm{p} / \mathrm{p})$ & 36.13 & 37.20 & 24.34 \\
\hline
\end{tabular}

The flowers and leaves of both species had similar lignocellulosic content. In contrast, the seeds and stems of G. monspessulana contained the most hemicellulose and cellulose, while those of $U$. europaeus contained more lignin. Overall, all functional parts had very high lignocellulosic content, exceeding $90 \%$ in total. Regarding the activation energy, U. europaeus had generally higher values for hemicellulose and cellulose, while G. monspessulana presented higher values for lignin. The only exception was 
the seeds in which both species had the same activation energy for hemicellulose. For example, the deconvolution of the DTG curve for stems in both species is illustrated in Figure 2 and showed that the increasing order of thermal decomposition was first hemicellulose, then cellulose, and finally lignin.

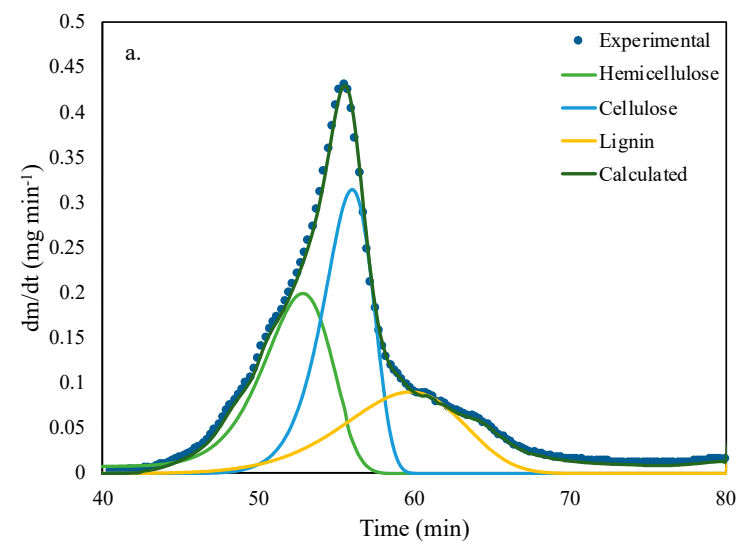

(a)

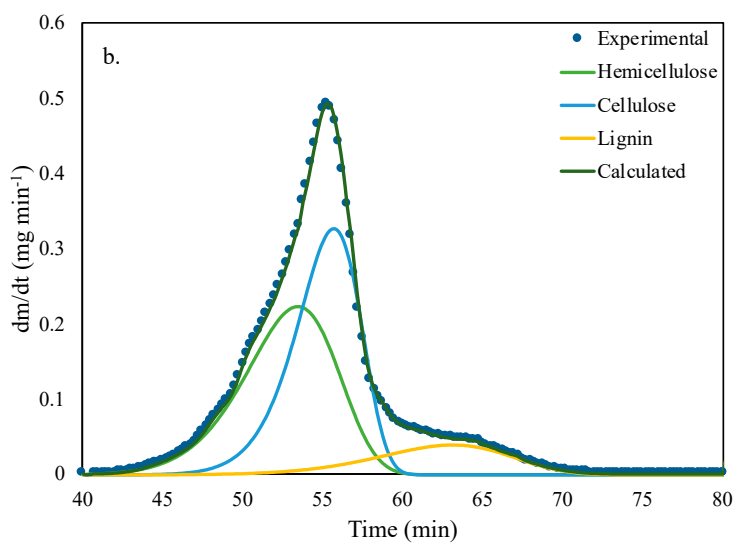

(b)

Figure 2. Deconvolution of the DTG curve corresponding to the degradation of (a) G-stem and (b) FB-stem.

\subsection{Essential Oils and Other Chemical Compounds}

After carrying out the extraction process by means of extraction of super critical fluids, several compounds could be detected in each functional part of the two species. Both species presented a large amount of essential oils, \pm 100 for U. europaeus and \pm 138 for $G$. monspessulana. Of all the organs analyzed in the extraction of essential oils, the stem of G. monspessulana is the functional part with more found compounds ( \pm 83 essential oils), which makes this functional part a potential advantage for the extraction of oils. The lowest amounts of compounds were found in the leaves and stems with \pm 31 oils essential each for $U$. europaeus, and in seeds with \pm 28 oil essential for $G$. monspessulana, while the other parts analyzed (flower and seed for U. europaeus and flower and leaf for G. monspessulana) showed \pm 43 compounds per functional part on average. Only flowers showed a similar number of compounds between the two species. G. monspessulana presented more compounds in leaves than $U$. europaeus, while in the seeds it was the opposite. There was also a net difference in stems, with G. monspessulana showing around 2.6 times more compounds than U. europaeus. Evaluating the shared compounds between the two species, nine in flowers, five in leaves, 16 in seeds, and 17 in stems were encountered (Table 3). It was proven, for example, that stearic acid was the only compound detected in all functional parts of the plants. Another shared compound of great interest was maltol, found mainly in G. monspessulana but also in the seeds of $U$. europaeus. Likewise, other interesting compounds such as acetic acid, dodecanoic acid, anagyrine, amylene hydrate, caulophylline, maltol, among others, were found in both species. 
Table 3. Compounds detected in the different functional parts of U. europaeus and G. monspessulana.

\begin{tabular}{|c|c|c|}
\hline Compound & U. europaeus & G. monspessulana \\
\hline (R)-(-)-14-Methyl-8-hexadecyn-1-ol & Seed & Flower and stem \\
\hline 1,2-15,16-Diepoxyhexadecane & Leaf and Seed & Flower and stem \\
\hline 1,2-Benzisothiazole, 3-(hexahydro-1H-azepin-1-yl)-, 1,1-dioxide & Flower, leaf and seed & \\
\hline 10,13-Octadecadienoic acid, methyl ester & Seed and stem & \\
\hline 12-Methyl-E,E-2,13-octadecadien-1-ol & Flower and leaf & stem \\
\hline 2,3-Butanediol & & Leaf, seed and stem \\
\hline 2-Methoxy-4-vinylphenol & Leaf and seed & Flower and leaf \\
\hline 2-Methyl-3-(3-methyl-but-2-enyl)-2-(4-methyl-pent-3-enyl)-oxetane & Flower and leaf & \\
\hline 2-Methyl-Z,Z-3,13-octadecadienol & Flower and leaf & \\
\hline 2-Pyrrolidinone & & Seed and stem \\
\hline 3-Buten-2-ol, 2-methyl- & Flower and seed & Flower and leaf \\
\hline 4-(2,6,6-Trimethylcyclohexa-1,3-dienyl)but-3-en-2-one & & Flower, leaf and stem \\
\hline 4H-Pyran-4-one, 2,3-dihydro-3,5-dihydroxy-6-methyl- & & Flower, leaf and seed \\
\hline 5,6-Dehydrolupanine & & Flower, leaf and stem \\
\hline 9,17-Octadecadienal, (Z)- & Flower and seed & Seed \\
\hline Acetic acid & All organs & Flower, seed and stem \\
\hline Amylene Hydrate & All organs & Flower and seed \\
\hline Anagyrine & Flower & Leaf and stem \\
\hline Aphyline & & All organs \\
\hline $\begin{array}{c}\text { Benzenepropanoic acid, 3,5-bis(1,1-dimethylethyl)-4-hydroxy-, methyl } \\
\text { ester }\end{array}$ & Flower, seed and stem & Flower, seed and stem \\
\hline Bufotenine & & All organs \\
\hline Butyrolactone & & Flower and stem \\
\hline Caulophylline & Seed & All organs \\
\hline Cyclododecane & Flower & Leaf and stem \\
\hline Cyclohexasiloxane, dodecamethyl- & Seed & Leaf and stem \\
\hline Cyclopentadecanone, 2-hydroxy- & & Flower and stem \\
\hline Cyclopropaneoctanal, 2-octyl- & Flower, leaf and seed & Stem \\
\hline Diethylene glycol monobutyl ether & Leaf and Seed & \\
\hline Dihydroactinidiolide & & Leaf and stem \\
\hline Eicosane & Flower, leaf and stem & Stem \\
\hline Ethanol, 1-(2-butoxyethoxy)- & Flower, leaf and stem & Seed and stem \\
\hline Heptadecane & Leaf & Flower and stem \\
\hline Lauric acid & Flower and seed & Flower, leaf and stem \\
\hline Linoleic Acid & Flower, leaf and seed & Flower, seed and stem \\
\hline Maltol & Seed & Flower, seed and stem \\
\hline Methyl linolenate & Flower and leaf & Flower and leaf \\
\hline Methyl palmitate & Flower, seed and stem & Seed and stem \\
\hline m-Xylene & Flower and stem & Seed \\
\hline Octadecane & Flower and stem & \\
\hline Oleamide & & Leaf and seed \\
\hline Oleic Acid & Flower and leaf & Stem \\
\hline Palmitic acid & Flower, leaf and stem & Leaf, seed and stem \\
\hline Phytol & Leaf and Seed & Flower, leaf and stem \\
\hline Psilocin & & Leaf and stem \\
\hline Pyridine, 3-methoxy- & Leaf and Seed & Seed and stem \\
\hline Squalene & Flower and stem & \\
\hline Stearic acid & All organs & All organs \\
\hline Tetracosane & & Flower and stem \\
\hline Tetradecanoic acid & Flower and seed & Flower and stem \\
\hline Triacetin & Seed & Seed and stem \\
\hline Undecane & Flower, seed and stem & \\
\hline Vitamin E & Leaf and stem & \\
\hline$\alpha$-Isoaphylline & & All organs \\
\hline
\end{tabular}

\section{Discussion}

U. europaeus and G. monspessulana are invasive species of high risk in Colombia, especially in high Andean ecosystems. Currently, there is very little data on their physicochemical characteristics, particularly for G. monspessulana. Therefore, an exhaustive characterization of the two species was carried out to determine their properties and advance potential uses and valorization processes. This study complements previous efforts to characterize and propose a strong scientifically-supported basis for environmental authorities and stakeholders to establish suited management strategies of these two invasive species. Therefore, in order to perform an adequate management of their invasions, it is very important to know how they have adapted to the new environment and how it may reflect in terms of physico-chemical properties. Because similar elemental and chemical composition was 
observed between the functional parts of $U$. europaeus and G. monspessulana, which can be due to their taxonomical proximity and ecological closeness, opportunities for similar proper management, at least in Colombia, can be created.

First, this study performed a separate HHV analysis of four functional parts of both species, whereas previous studies had only carried out HHV analysis on U. europaeus and analyzing the whole plant. Our results coincided with previous findings; for example, Saldarriaga et al. [34] found an HHV of $19.43 \mathrm{MJ} / \mathrm{kg}$ for U. europaeus. We found high HHVs for all functional parts, very similar to those of pine sawdust, which is one of the most commonly used biomasses for thermal processes worldwide [39,41-43]. In general, the volatile matter of both species was very high while the ash content was very low, which, according to Vassilev et al. [41], is important because where there is a higher volatile content in a thermal process, the yield of biomass includes light hydrocarbons, $\mathrm{CO}, \mathrm{CO}_{2}$, $\mathrm{H}_{2}$, moisture and tars. Regarding the elemental analysis, previous studies had quantified the content of $\mathrm{C}, \mathrm{H}, \mathrm{O}, \mathrm{N}, \mathrm{P}, \mathrm{K}, \mathrm{S}, \mathrm{Ca}, \mathrm{Mg}, \mathrm{Na}, \mathrm{Cu}, \mathrm{Fe}, \mathrm{Mn}, \mathrm{Zn}$, and $\mathrm{Si}$ for leaves and stems of $U$. europaeus [44]. However, the sum of elements different to CHONS is under $2.5 \mathrm{wt} . \%$, which indicates that the only quantification of CHONS is a very good approximation. Because no elemental analyses had been previously carried out on G. monspessulana to our knowledge, the comparison of our results with past findings was not possible. Results found in literature showed certain biofuel potential for energy production and could be used for heating in cold mountain areas thanks to their substantial HHV (in comparison to fuelwood and crop residues with 17.50 and $36.80 \mathrm{MJ} / \mathrm{kg}$ values, respectively $[41,45])$.

Second, our results suggested that these species can undergo invasion management by the means of pyrolysis or combustion processes in order to obtain energy. This strategy would be particularly valuable in Colombian mountains where climatic conditions are usually highly variable and harsh $\left(\sim 2-10^{\circ} \mathrm{C}\right.$ across the altitudinal gradient). Our kinetic model proposed for U. europaeus and G. monspessulana of oxidative pyrolysis had the same behavior as those reported by literature $[39,46]$. The pyrolysis of both species registered two peaks: the first one shifted to lower temperatures than those corresponding to inert pyrolysis $\left(0 \%\right.$ of $\left.\mathrm{O}_{2}\right)$, and the second one to higher temperature corresponding to char combustion. Moreover, the behavior observed in this study was similar to that observed by other authors in which hemicellulose is the least thermally stable fraction of the two species studied, mainly due to the presence of acetyl groups [47]. The degradation of lignin began at relatively low temperatures and continued over a wide range of temperatures [48], while cellulose had high thermal stability, surely due to its crystalline structure [49]. As encountered in previous studies, our results showed that, once the degradation of cellulose had begun, a very quick degradation process occurred and the characteristic peak of the deconvolved DTG curve was produced $[34,39]$. Therefore, it was verified again that the tool developed by other authors works very well [39]. It provides a good fit between the experimental and calculated data: it allows part of the calculations of the content of the natural polymers of both species, and it also determines the kinetic parameters of the pyrolysis process. The two species can also be used in a pyrolysis process to obtain char and/or other components. As they have low nitrogen and sulfur content, the production of SOx and NOx is expected not to be a major concern. In addition, they are very good raw material for several industrial processes due to their lignocellulosic composition. For example, carbon fibers from lignin, cellulose whiskers, bioethanol from cellulose, and hemicellulose can be obtained [50]. Likewise, their high volatile matter and low ashes content make them ideal for gasification processes; however, only U. europaeus is ideal for activated carbon obtention due to its fixed carbon content [34].

There are few studies reported in the literature regarding the oil's extraction in both species, as for G. monspessulana there are few reports of oil extraction, in which the presence of cytisine, aphylline, and anagyrine among others has been reported [51,52], while Parra [53] carried out an extraction of essential oils on $U$. europaeus by using steam distillation and found 90 compounds compared to our 100 (over $90 \%$ certainty), of which only two, heptadecane and eicosane, matched. This difference may be due to the extraction process and the solvent drying technique. Similarly, studies conducted in Portugal and Spain, where this species is native (U. europaeus), can identify by different techniques essential 
oils such as acacetin, caffeic acic, cytisine, anagyrine, ferulic acid, xylose, xylan, arabinose, among others $[27,54-56]$. We believe that many chemical components that can be extracted for industrial use have been identified. For example, the stearic acid (also called octadecanoic acid) is currently used to activate the phase change performance of composite materials due to its excellent properties, such as the range of fusion temperature and the high thermal capacity. Similarly, maltol is catalogued as an important and powerful flavoring additive, which is widely used in food production [57]. This could be extracted from the seeds of both plants and be used to improve the processing and food shelf life [58]. In addition, maltol is a number of gamma pyrones that has wide applications in many chemical syntheses as a ligand. Another important compound is acetic acid, which was found in both species. This can be used in agriculture in the control of larvae and the eggs of the wax moths, since it destroys the wax combs $[59,60]$. Other studies suggest useful effects against pathogens in a variety of food products such as moutable (eggplant dip) [61,62], salads [63,64], hummus [65], and tahini [66,67]. Other essential components such as eicosane, palmitic acid, and oleic acid found in this study in both species have also been reported in studies of jatropha. These compounds are widely used in cosmetics, lubricants, among others. All of the above means that both species can become an important source of these types of chemical compounds, and could potentially profit from sustainable harvest by Andean communities.

Finally, the methodology used for the extraction of essential oils and other chemical compounds of interest could still improve in several ways. For example, adapting the drying method carried out on all samples before analyzing them would be useful in order to avoid the volatilization of certain chemical compounds of interest. Moreover, regarding essential oils extraction, other solvents could be tested in small volumes, with more samples or longer extraction time to obtain more concentrated extracts and thus increase the number of compounds detected in the chromatography. We also recommend conducting a deeper analysis to determine the quantity of each compound, in order to estimate extraction levels for future sustainable exploitation.

\section{Conclusions}

U. europaeus and G. monspessulana are two invasive species that have colonized several ecosystems in the Colombian Andes. To perform an adequate environmental management of their invasions, it is very important to know how they have adapted to their new environment and what physical and chemical characteristics they present. Our study found many similarities between these two species, which could facilitate their environmental management and control. Thanks to their physicochemical properties, they both can be used in several processes such as pyrolysis, gasification, and combustion, but only $U$. europaeus shows an adequate composition for obtaining activated carbon. They also have a high lignocellulosic content useful in the production of carbon fibers, whiskers, bioethanol, among others. Furthermore, these species contain many crucial essential oils and other chemical compounds such as acetic acid, maltol, and stearic acid, which turn out to be interesting in agriculture for the control of pests, in the industry of food to preserve food, among other uses.

Author Contributions: Study conception and design: G.P. and J.F.S.; Acquisition of data: D.F.O.-C., G.P. and J.F.S.; Analysis and interpretation of data: D.F.O.-C., G.P. and J.F.S.; Drafting of manuscript: D.F.O.-C., G.P. and J.F.S.; Critical revision: D.F.O.-C., G.P. and J.F.S. All authors have read and agreed to the published version of the manuscript.

Acknowledgments: We thank the Department of Civil and Environmental Engineering for their financial support. Juan F. Saldarriaga thanks financial support from the University of Los Andes for the Early-Stage Research Fund -FAPA- (P3.2017.3830). Gwendolyn Peyre thanks financial support from the University of Los Andes for the Early-Stage Research Fund -FAPA- (P3.2016.3708).

Conflicts of Interest: The authors declare no conflict of interest. 


\section{References}

1. Dragicevic, A.Z. Comparing forest governance models against invasive biological threats. J. Theor. Biol. 2019, 462, 270-282. [CrossRef] [PubMed]

2. CABI. Genista Monspessulana (Montpellier Broom). Available online: https://www.cabi.org/isc/datasheet/ 25059\#BFC61822-C72D-4D93-960A-66CDDF034DE4 (accessed on 20 September 2019).

3. Minambiente. Invasive Exotic Species; Minambiente: Bogotá, Colombia, 2010; Volume 207, p. 7.

4. León, O.; Vargas, O. Las especies invasoras: Un reto para la restauración ecológica. In Restauración Ecológica en Zonas Invadidas por Retamo Espinoso y Plantaciones Forestales de Especies Exóticas; Universidad Nacional de Colombia: Bogotá, Colombia, 2009; pp. 19-38.

5. Baptiste, M.P.; Castaño, N.; Cárdenas, D.; Gutiérrez, F.P.; Gil, D.; Lasso, C. Análisis de Riesgo y Propuesta de Categorización de Especies Introducidas para Colombia; Instituto de Investigación en Recursos Biológicos Alexander von Humboldt: Bogotá, Colombia, 2010; ISBN 978-958-8343-46-4.

6. Petitpierre, B.; Kueffer, C.; Broennimann, O.; Randin, C.; Daehler, C.; Guisan, A. Climatic Niche Shifts Are Rare Among Terrestrial Plant Invaders. Science 2012, 335, 1344-1348. [CrossRef] [PubMed]

7. Lowe, S.; Browbe, M.; Boudjelas, S.; De Poorter, M. 100 of the World's Worst Invasive Alien Species A Selection from the Global Invasive Species Database, 2nd ed.; The Invasive Species Specialist Group (ISSG) a Specialist Group of the Species Survival Commission (SSC) of the World Conservation Union (IUCN): Auckland, New Zealand, 2004.

8. Díaz, A.M.; Vargas, O. Chapter 3. Rasgos de historia de vida y ecología de las invasiones de Ulex europaeus. In Restauración Ecológica en Zonas Invadidas por Retamo Espinoso y Plantaciones Forestales de Especies Exóticas; Universidad Nacional de Colombia: Bogotá, Colombia, 2009; pp. 59-67, ISBN 978-958-719-314-5.

9. Lee, W.G.; Allen, R.B.; Johnson, P.N. Succession and dynamics of gorse (Ulex europaeus L.) communities in the dunedin ecological district South Island, New Zealand. N. Z. J. Bot. 1986, 24, 279-292. [CrossRef]

10. Ivens, G.W. Some aspects of seed ecology of gorse [Ulex europaeus]. Proc. N. Z. Weed Pest Control Conf. 1978, 31, 53-57.

11. Alexander, J.M.; D'Antonio, C.M. Seed Bank Dynamics of French Broom in Coastal California Grasslands: Effects of Stand Age and Prescribed Burning on Control and Restoration. Restor. Ecol. 2003, 11, 185-197. [CrossRef]

12. Popay, A.I.; Adams, C. Emergence of gorse seedlings from a root-raked area. In Proceedings of the Forty Third New Zealand Weed and Pest Control Conference, Dunedin, New Zealand, 14-16 August 1990; pp. 166-169.

13. Ríos, H.F. Guía Técnica para la Restauración Ecológica de Áreas Afectadas por Especies Vegetales Invasoras en el Distrito Capital: Complejo Invasor Retamo Espinoso (Ulex europaeus L.) -Retamo Liso (Teline Monspessulana (L) C. Koch.); Jardin Botanico Jose Celestino Mutis: Bogotá, Colombia, 2005; ISBN 978-958-96823-9-5.

14. Vargas, O. Restauración Ecológica del Bosque Altoandino - Estudios Diagnósticos y Experimentales en los Alrededores del Embalse de Chisacá, Localidad de Usme, Bogotá; Universidad Nacional de Colombia: Bogotá, Colombia, 2007; ISBN 978-958-701-848-6.

15. Pauchard, A.; García, R.A.; Peña, E.; González, C.; Cavieres, L.A.; Bustamante, R.O. Positive feedbacks between plant invasions and fire regimes: Teline monspessulana (L.) K. Koch (Fabaceae) in central Chile. Biol. Invasions 2008, 10, 547-553. [CrossRef]

16. García, R.A.; Engler, M.L.; Peña, E.; Pollnac, F.W.; Pauchard, A. Fuel characteristics of the invasive shrub Teline monspessulana (L.) K. Koch. Int. J. Wildland Fire 2015, 24, 372-379. [CrossRef]

17. Gonzalez-Andres, F.; Ortiz, J.-M. Specificity of Rhizobia Nodulating Genista monspessulana and Genista linifolia In Vitro and in Field Situations. Arid Soil Res. Rehabil. 1999, 13, 223-237. [CrossRef]

18. Cano, I.; Zamudio, N. Chapter 2. Estrategias de articulación y participación comunitaria con los proyectos de restauración ecológica. In Restauración Ecológica del Bosque Altoandino. Estudios Diagnósticos y Experimentales en los Alrededores del Embalse de Chisacá (Localidad de Usme, Bogotá D.C.); Universidad Nacional de Colombia: Bogotá, Colombia, 2007; pp. 104-145, ISBN 978-958-701-848-6.

19. Alarcón, E.; Lozano de Yunda, A.; Chaparro, H. Caracterización fenotípica de aislamientos rizobianos de Acacia (Acacia sp.) y retamo (Teline monspessulana). Rev. Colomb. Quím. 1997, 26, 21-33.

20. Smith, J.M.B. An introduction to the biogeography and ecology of broom (Cytisus scoparius) in Australia. Plant Prot. Q. 2000, 15, 140-144. 
21. García, R.A.; Fuentes-Ramírez, A.; Pauchard, A. Effects of two nitrogen-fixing invasive plants species on soil chemical properties in south-central Chile. Gayana Bot. 2012, 69, 189-192. [CrossRef]

22. Parsons, W.T.; Cuthbertson, E.G. Noxious Weeds of Australia, 2nd ed.; CSIRO Publishing: Clayton, Victoria, 2001; ISBN 978-0-643-06514-7.

23. CABI Ulex Europaeus (Gorse). Available online: https://www.cabi.org/isc/datasheet/55561 (accessed on 22 February 2019).

24. Ríos, A. Eliminación de la Especie Invasora Ulex Europaeus L. (Fabaceae) Como Estrategia Experimental de Restauración de la Vegetación del Cerro de Monserrate, Bogotá. Ph.D. Thesis, Universidad Nacional de Colombia, Bogotá, Colombia, 2001.

25. Hornoy, B.; Tarayre, M.; Hervé, M.; Gigord, L.; Atlan, A. Invasive Plants and Enemy Release: Evolution of Trait Means and Trait Correlations in Ulex europaeus. PLoS ONE 2011, 6, e26275. [CrossRef] [PubMed]

26. Altamirano, A.; Cely, J.P.; Etter, A.; Miranda, A.; Fuentes-Ramirez, A.; Acevedo, P.; Salas, C.; Vargas, R. The invasive species Ulex europaeus (Fabaceae) shows high dynamism in a fragmented landscape of south-central Chile. Environ. Monit. Assess 2016, 188, 495. [CrossRef] [PubMed]

27. López-Hortas, L.; Conde, E.; Falqué, E.; Domínguez, H. Flowers of Ulex europaeus L.—Comparing two extraction techniques (MHG and distillation). Comptes Rendus Chim. 2016, 19, 718-725. [CrossRef]

28. Udo, N.; Darrot, C.; Atlan, A. From useful to invasive, the status of gorse on Reunion Island. J. Environ. Manag. 2019, 229, 166-173. [CrossRef]

29. Morin, L.; Gianotti, A.F.; Lauren, D.R. Trichothecene production and pathogenicity of Fusarium tumidum, a candidate bioherbicide for gorse and broom in New Zealand. Mycol. Res. 2000, 104, 993-999. [CrossRef]

30. López-López, N.; López-Fabal, A. Compost based ecological growing media according EU eco-label requirements. Sci. Hortic. 2016, 212, 1-10. [CrossRef]

31. Audette, G.F.; Vandonselaar, M.; Delbaere, L.T. The 2.2 A resolution structure of the $\mathrm{O}(\mathrm{H})$ blood-group-specific lectin I from Ulex europaeus. J. Mol. Biol. 2000, 304, 423-433. [CrossRef]

32. Kostova, I.N.; Nikolov, N.M.; Chipilska, L.N. Antimicrobial properties of some hydroxycoumarins and Fraxinus ornus bark extracts. J. Ethnopharmacol. 1993, 39, 205-208. [CrossRef]

33. Mongrand, S.; Bessoule, J.-J.; Cabantous, F.; Cassagne, C. The C16:3 \C18:3 fatty acid balance in photosynthetic tissues from 468 plant species. Phytochemistry 1998, 49, 1049-1064. [CrossRef]

34. Saldarriaga, J.F.; Patiño, J.L.; Lizarazo, M.J. Kinetic Study of Spiny Retamo (Ulex Eurioaeus, L.) Waste Oxidative Pyrolysis. Chem. Eng. Trans. 2018, 70, 1249-1254.

35. Ocampo-Zuleta, K.; Solorza-Bejarano, J. Banco de semillas de retamo espinoso Ulex europaeus L. en bordes del matorral invasor en un ecosistema zonal de bosque altoandino, Colombia. Biota Colomb. 2017, 18, 89-98. [CrossRef]

36. Zabaleta, A. Caracterización horizontal y vertical de los bancos de semillas germinables de Ulex europaeus L. (Fabaceae) en parches de diferentes tamaños en el Embalse de Chisacá Localidad de Usme, Bogotá, D.C. In Restauración Ecológica del Bosque Altoandino. Estudios Diagnósticos y Experimentales en los Alrededores del Embalse de Chisacá (Localidad de Usme, Bogotá D.C.); Universidad Nacional de Colombia: Bogotá, Colombia, 2007; pp. 353-367, ISBN 978-958-701-848-6.

37. Thuiller, W.; Georges, D.; Engler, R.; Breiner, F. Biomod2: Ensemble Platform for Species Distribution Modeling. R Package Vers. 2013, 2, r560.

38. Karger, D.N.; Conrad, O.; Böhner, J.; Kawohl, T.; Kreft, H.; Soria-Auza, R.W.; Zimmermann, N.E.; Linder, H.P.; Kessler, M. Climatologies at high resolution for the earth's land surface areas. Sci. Data 2017, 4, 1-20. [CrossRef] [PubMed]

39. Saldarriaga, J.F.; Aguado, R.; Pablos, A.; Amutio, M.; Olazar, M.; Bilbao, J. Fast characterization of biomass fuels by thermogravimetric analysis (TGA). Fuel 2015, 140, 744-751. [CrossRef]

40. Gaspar, F. Extraction of Essential Oils and Cuticular Waxes with Compressed CO2: Effect of Extraction Pressure and Temperature. Ind. Eng. Chem. Res. 2002, 41, 2497-2503. [CrossRef]

41. Vassilev, S.V.; Baxter, D.; Andersen, L.K.; Vassileva, C.G. An overview of the chemical composition of biomass. Fuel 2010, 89, 913-933. [CrossRef]

42. Saldarriaga, J.F.; Grace, J.; Lim, C.J.; Wang, Z.; Xu, N.; Atxutegi, A.; Aguado, R.; Olazar, M. Bed-to-surface heat transfer in conical spouted beds of biomass-sand mixtures. Powder Technol. 2015, 283, 447-454. [CrossRef]

43. Saldarriaga, J.F.; Aguado, R.; Atxutegi, A.; Grace, J.; Bilbao, J.; Olazar, M. Correlation for Calculating Heat Transfer Coefficient in Conical Spouted Beds. Ind. Eng. Chem. Res. 2016, 55, 9524-9532. [CrossRef] 
44. Lambert, M.G.; Jung, G.A.; Harpster, H.W.; Lee, J. Forage shrubs in North Island hill country 4. Chemical composition and conclusions. N. Z. J. Agric. Res. 1989, 32, 499-506. [CrossRef]

45. Vassilev, S.V.; Baxter, D.; Andersen, L.K.; Vassileva, C.G.; Morgan, T.J. An overview of the organic and inorganic phase composition of biomass. Fuel 2012, 94, 1-33. [CrossRef]

46. Amutio, M.; Lopez, G.; Aguado, R.; Artetxe, M.; Bilbao, J.; Olazar, M. Kinetic study of lignocellulosic biomass oxidative pyrolysis. Fuel 2012, 95, 305-311. [CrossRef]

47. Yang, H.; Yan, R.; Chen, H.; Lee, D.H.; Zheng, C. Characteristics of hemicellulose, cellulose and lignin pyrolysis. Fuel 2007, 86, 1781-1788. [CrossRef]

48. Yang, H.; Yan, R.; Chen, H.; Zheng, C.; Lee, D.H.; Liang, D.T. In-Depth Investigation of Biomass Pyrolysis Based on Three Major Components: Hemicellulose, Cellulose and Lignin. Energy Fuels 2006, 20, 388-393. [CrossRef]

49. Sebio-Puñal, T.; Naya, S.; López-Beceiro, J.; Tarrío-Saavedra, J.; Artiaga, R. Thermogravimetric analysis of wood, holocellulose, and lignin from five wood species. J. Therm. Anal. Calorim. 2012, 109, 1163-1167. [CrossRef]

50. Sharma, A.; Thakur, M.; Bhattacharya, M.; Mandal, T.; Goswami, S. Commercial application of cellulose nano-composites-A review. Biotechnol. Rep. 2019, 21, e00316. [CrossRef]

51. Boulanouar, B.; Abdelaziz, G.; Aazza, S.; Gago, C.; Miguel, M.G. Antioxidant activities of eight Algerian plant extracts and two essential oils. Ind. Crops Prod. 2013, 46, 85-96. [CrossRef]

52. Nihei, K.; Shibata, K.; Kubo, I. (+)-2,3-Dehydro-10-oxo- $\alpha$-isosparteine in Uresiphita reversalis larvae fed on Cytisus monspessulanus leaves. Phytochemistry 2002, 61, 987-990. [CrossRef]

53. Parra, C. Actividad Antimicrobiana y Caracterización Química del Aceite Esencial de Ulex Europaeus L. (Fabaceae); Universidad Dristrial Francisco José de Caldas: Bogotá, Colombia, 2017.

54. Máximo, P.; Lourenço, A.; Tei, A.; Wink, M. Chemotaxonomy of Portuguese Ulex: Quinolizidine alkaloids as taxonomical markers. Phytochemistry 2006, 67, 1943-1949. [CrossRef]

55. Spínola, V.; Llorent-Martínez, E.J.; Gouveia-Figueira, S.; Castilho, P.C. Ulex europaeus: From noxious weed to source of valuable isoflavones and flavanones. Ind. Crops Prod. 2016, 90, 9-27. [CrossRef]

56. Ligero, P.; de Vega, A.; van der Kolk, J.C.; van Dam, J.E.G. Gorse (Ulex europæus) as a possible source of xylans by hydrothermal treatment. Ind. Crops Prod. 2011, 33, 205-210. [CrossRef]

57. Li, J.; Hao, H.; Guo, N.; Wang, N.; Hao, Y.; Luan, Y.; Chen, K.; Huang, X. Solubility and thermodynamic properties of maltol in different pure solvents. J. Mol. Liq. 2017, 243, 313-323. [CrossRef]

58. Gan, T.; Lv, Z.; Liu, N.; Sun, J.; Shi, Z.; Zhao, A. Ultrasensitive Electrochemical Sensor for Maltol in Wines Using Graphene Oxide-Wrapped Amino-Functionalized Carbon Sphere as Sensing Electrode Materials. Electroanalysis 2016, 28, 103-110. [CrossRef]

59. Al-Ghamdi, A.; Ali Khan, K.; Javed Ansari, M.; Almasaudi, S.B.; Al-Kahtani, S. Effect of gut bacterial isolates from Apis mellifera jemenitica on Paenibacillus larvae infected bee larvae. Saudi J. Biol. Sci. 2018, 25, 383-387. [CrossRef] [PubMed]

60. Hamdi, C.; Balloi, A.; Essanaa, J.; Crotti, E.; Gonella, E.; Raddadi, N.; Ricci, I.; Boudabous, A.; Borin, S.; Manino, A.; et al. Gut microbiome dysbiosis and honeybee health. J. Appl. Entomol. 2011, 135, 524-533. [CrossRef]

61. Skandamis, P.N.; Nychas, G.-J.E. Development and Evaluation of a Model Predicting the Survival of Escherichia coli O157:H7 NCTC 12900 in Homemade Eggplant Salad at Various Temperatures, pHs, and Oregano Essential Oil Concentrations. Appl. Environ. Microbiol. 2000, 66, 1646-1653. [CrossRef]

62. Osaili, T.M.; Al-Nabulsi, A.A.; Jaradat, Z.; Shaker, R.R.; Alomari, D.Z.; Al-Dabbas, M.M.; Alaboudi, A.R.; Al-Natour, M.Q.; Holley, R.A. Survival and growth of Salmonella Typhimurium, Escherichia coli O157:H7 and Staphylococcus aureus in eggplant dip during storage. Int. J. Food Microbiol. 2015, 198, 37-42. [CrossRef]

63. Alali, W.Q.; Mann, D.A.; Beuchat, L.R. Viability of Salmonella and Listeria monocytogenes in Delicatessen Salads and Hummus as Affected by Sodium Content and Storage Temperature. J. Food Prot. 2012, 75, 1043-1056. [CrossRef]

64. Tassou, C.C.; Samaras, F.J.; Arkoudelos, J.S.; Mallidis, C.G. Survival of acid-adapted or non-adapted Salmonella Enteritidis, Listeria monocytogenes and Escherichia coli O157:H7, in traditional Greek salads. Int. J. Food Sci. Technol. 2009, 44, 279-287. [CrossRef]

65. Al-Holy, M.; Al-Qadiri, H.; Lin, M.; Rasco, B. Inhibition of Listeria innocua in Hummus by a Combination of Nisin and Citric Acid. J. Food Prot. 2006, 69, 1322-1327. [CrossRef] 
66. Al-Rousan, W.M.; Olaimat, A.N.; Osaili, T.M.; Al-Nabulsi, A.A.; Ajo, R.Y.; Holley, R.A. Use of acetic and citric acids to inhibit Escherichia coli O157:H7, Salmonella Typhimurium and Staphylococcus aureus in tabbouleh salad. Food Microbiol. 2018, 73, 61-66. [CrossRef] [PubMed]

67. Al-Nabulsi, A.A.; Olaimat, A.N.; Osaili, T.M.; Shaker, R.R.; Zein Elabedeen, N.; Jaradat, Z.W.; Abushelaibi, A.; Holley, R.A. Use of acetic and citric acids to control Salmonella Typhimurium in tahini (sesame paste). Food Microbiol. 2014, 42, 102-108. [CrossRef] [PubMed]

(C) 2019 by the authors. Licensee MDPI, Basel, Switzerland. This article is an open access article distributed under the terms and conditions of the Creative Commons Attribution (CC BY) license (http://creativecommons.org/licenses/by/4.0/). 